\title{
Occupational Health and Safety and Job Satisfaction: The Moderating Effect of Role Ambiguity
}

\author{
İşSağlı̆̆ı ve Güvenliği ve İş Tatmini: Rol Belirsizliğinin Düzenleyici Etkisi
}

\author{
Mehmet Ali Türkmenoğlu*
}

\begin{abstract}
Öz: Fiziksel çalışma koşullarından kaynaklanan sağlık sorunlarını azaltmak ve ortadan kaldırmak için iş sağlı̆̆ı ve güvenliği tedbirlerinin alınması ve denetlenmesi gerektiği araştırmacılar tarafından ortaya konulmaktadır. İş sağllğı ve güvenliği ile ilgili çokça araştırma yürütülmesine rağmen iş sağlığı ve güvenliği uygulamalarının, çalışan davranışları üzerindeki etkilerinin neler olabileceği ile ilgili yürütülen çalışmalar görece sınırlı kalmıştır. Bu nedenle, bu çalışmanın amacı iş sağlığı ve güvenliğinin iş tatmini üzerindeki etkisini incelemek ve rol belirsizliğinin, bu ilişkideki düzenleyici etkisini ortaya koymaktır. Araştırmanın amacına ulaşmasıı adına, verinin toplanması ve analiz edilmesi için nicel yöntemler benimsenmiştir. Muş Alparslan Üniversitesi Bilimsel Araştırma ve Yayın Etiği Kurulu, bu araştırmanın yürütülmesini 26/11/2020 tarih ve E-10879717-050.01.04-13802 sayılı karar ile uygun görmüştür. Bursa'daki mobilya imalat firmalarında çalışan 202 katılımcı çalışmanın örneklemini oluşturmuştur. Elde edilen veriler SPSS v22 yazılımı kullanılarak çoklu regresyon analizine tabi tutulmuştur. Sonuçlar, iş sağlı̆̆ ve güvenliği uygulamalarının çalışanların iş tatminini olumlu yönde etkilediğini göstermiştir. Ayrıca analizler, iş sağlığı ve güvenliği ile iş tatmini arasındaki ilişkide rol belirsizliğinin düzenleyici bir rol oynadığını göstermiştir. Araştırmanın yazına sunduğu model üç değişkeni ilk defa bütünleşik bir şekilde incelemesi çalışmanın özgünlüğünü ortaya koymaktadır. Ayrıca araştırmanın katkıları, sınırlılıkları, önerileri ve gelecek çalışmalara yön gösterebilecek hususları tartışılmışıtır.
\end{abstract}

Anahtar Kelimeler: İş Sağlığı ve Güvenliği, İş Tatmini, Rol Belirsizliği, Nicel Araştırma

\begin{abstract}
It is revealed by researchers that occupational health and safety measures should be taken and inspected to reduce and eliminate health problems arising from physical working conditions. Although numerous studies have been carried out on occupational health and safety, the effects of occupational health and safety practices on employee behaviour has not been fully researched which remains as an intriguing area. Therefore, the aim of this study is to examine the effect of occupational health and safety on job satisfaction and to reveal the moderator effect of role ambiguity on this relationship. To achieve the aim of the research, quantitative methods were adopted to collect and analyse data. Muş Alparslan University Scientific Research and Publication Ethics Committee approved the conduct of this research with the decision dated 26/11/2020 and numbered E-10879717-050.01.0413802. 202 participants from furniture manufacturing firms in Bursa, Turkey provided valid questionnaires. Multiple regression analysis was conducted using SPSS v22 software. The results suggested that occupational health and safety positively influences the job satisfaction of employees. Furthermore, the analysis showed that role ambiguity plays a moderating role on the relationship between occupational health and safety and job satisfaction. The contribution that the research model makes to the literature is unique as it is the first model that

\footnotetext{
*Asst. Prof. Dr., Business Administration Department, Faculty of Economics and Administrative Sciences, Muş Alparlsan University ORCID: 0000-0001-5668-2184, m.turkmenoglu@alparslan.edu.tr

Received/Geliş: 30 April/Nisan 2021

Accepted/Kabul: 28 July/Temmuz 2021

Düzeltme/Revised form: 08 July/Temmuz 2021

Published/Yayın: 31 August/Ağustos 2021
}

e-ISSN: 2149-4622. ( ) 2013-2021 Muş Alparslan Üniversitesi. TÜBİTAK ULAKBİM DergiPark ev sahipliğinde. Her hakk1 saklıdır. http://dx.doi.org/10.18506/anemon.930688 
integrates the three variables work together in a theoretically meaningful way. In addition, the contributions, limitations, recommendations and aspects of the research that will inspire future studies are discussed.

Keywords: Occupational Health and Safety, Job Satisfaction, Role Ambiguity, Quantitative Research

\section{Introduction}

Over the past half-century, occupational health and safety (OHS) has been increasingly vital to employees, organisations and society. OHS is about reducing or eliminating the health problems of employees due to the physical conditions in the workplace (Balkır, 2012). OHS has been essential as an average of 6000 workers lose their lives in a single day due to occupational accidents, which equals around 2 million people die worldwide. According to International Labour Organization (ILO), approximately 340 million occupational accidents occur, and 160 million individuals are affected by occupational accidents (ILO, 2021). Turkey has been suffering from occupational accidents as being rated the country with the highest number of occupational accidents in Europe (Ceylan, 2021). These statistics cannot emphasise enough OHS measures that need to be taken and applied in the workplace. OHS has begun gaining attention after the emergence of mass production factories and the impact of their poor work conditions on workers. Occupational hazards that have caused many deaths and left physically disabled people illustrated the need for taking action regarding these matters. Hence, unions have put pressure on governments and employers to offer better working conditions and decent pay. OHS is not limited to taking only precautions against risks and dangers at work; it also includes all work-related illnesses even outside of the workplace as well as social security regulations.

OHS is related to working conditions, which can be considered a subject of management. In particular, the impact of OHS might be examined in the context of organisational behaviour. Studies have shown that the quality of working conditions has notable impacts on employees' work-related behaviours (Faragher, Cass \& Cooper, 2005). Research demonstrated that those employees who perceive their workplaces as safe and comfortable tend to have higher performance (Nanzushi, 2015) and productivity (Bunn III, Pikelny, Slavin \& Paralkar, 2001). Moreover, early scientific management figures such as Taylor investigated if the conditions of the workplace had effects on workers behaviours as well. From this point of view, it was wondered if occupational health and safety would affect the job satisfaction of employees. At the same time, I was curious about any possible variable, which could moderate the relationship between OHS and job satisfaction. After reviewing the literature, it emerged role ambiguity that is defined as having clear instructions of tasks at work and knowing what to do for the job, could moderate the relationship above. This is because studies report that role ambiguity creates confusion among employees and often decreases job performance. Therefore, it was theoretically meaningful to include role ambiguity in the study as a moderator variable that would also extend the current literature. Given the relevance of OHS to organisational behaviour literature, this study aims to propose a research model to examine the impact of occupational health and safety on job satisfaction and the moderating effect of role ambiguity on this relationship. This study contributes to the literature by offering a novel model, which no research interrogated the relationships between these variables together.

This paper is organised as follows; an introduction that includes the rationale of the study is given at the outset of the paper. Then the theoretical framework of research is outlined, explaining variables and arguments for developing hypotheses. After that, methods including data collection, sampling and analytical procedures are presented. The paper is concluded by offering a discussion and conclusion section after laying out the results section.

\section{Theoretical Framework and Hypotheses}

\section{Occupational Health and Safety}

Work-related accidents, injuries, and deaths of people go all the way back to Ancient Egypt. It is recounted that as a result of deaths and permanent bodily damages that occurred during construction of the pyramids in Egypt, the existence of such problems started to be expressed (Çiçek \& Öçal, 2016). It 
is an undeniable fact that since the start of time, human beings have been subjected to poor working conditions during different periods and that there are limited state precautions in this regard. Increasing occupational hazards after the Industrial Revolution demonstrated the need for regulations in this area. Particularly during this period, consequences such as an increase in occupational diseases, arbitrary treatments in working hours, and an increase in child labour came to the fore due to insufficient safety, health, and security precautions (Abrams, 2001). Such developments did not only affect workers but also had an impact on businesses because they were faced with serious production losses and inefficiencies and had to sustain economic costs. This negative situation did not only decrease the competitive power of businesses but also gave negative consequences at the national level. With the recognition of the necessity to prioritise worker health, all parties, that is, workers, employers, and public institutions, came together and agreed on improving work conditions (Barling \& Griffiths, 2003). As a result of similar developments in the world, ILO was established to protect equitable human and labour rights. Countries became signatories to ILO agreements and played major roles to improve working conditions. In Turkey, improvements in laws started from the 1920s onwards. For instance, in 1921, issues concerning the labour conditions of workers at coal mines in Zonguldak and its vicinity were regulated. In 1924 the law giving one day of holiday entitlement a week was passed (Yiğit, 2005). From those days to today, as a result of negotiations with institutions that develop regulations and applications on this subject and that recommend realisation of applications such as the International Labour Organization, World Health Organization, and the European Union, significant progress was achieved on Occupational Health and Safety (Gençler, 2007).

From a general framework, Occupational Health and Safety can be described as worker's working in conditions suitable to human honour in every way. When this concept, which is formed of a twofold set, is described in more detail, it could be understood that occupational safety is a safety system reducing risks at the workplace and taking precautions against hazards. Similarly, occupational health can be described as ensuring worker's mental and physical well-being and sustainability (Balkır, 2012). According to the definition made by the ILO and the World Health Organization in 1950, OHS is "the promotion and maintenance of the highest degree of physical, mental and social well-being of workers in all occupations by preventing departures from health, controlling risks and the adaptation of work to people, and people to their jobs." However, based on changing and transforming technologies and work systems, this definition was expanded and revised as "the promotion and maintenance of the highest degree of physical, mental and social well-being of workers in all occupations, by preventing departures and protecting workers against risks due to unfavourable health conditions at work, placing and sustaining workers to work environments suitable to their physiological and psychological abilities, in summary assigning of work to people, and people to their jobs and adaptation to work" (Tambay, 2018).

As it can be understood from the expansion of the content of definition, OHS is not limited to improvement of work conditions, relationships, and environment of workers, but it is a factor that directly affects the quality of life of workers with increasing scope over time. In countries where OHS applications are broadly enforced, OHS takes stakeholders affected by business activities under protection. In addition, it also protects customers and visitors of businesses from hazards. With these dimensions, OHS does not only ensure the safety of workers and stakeholders but also plays a major role in the development of the culture of safety in institutions.

\section{Job Satisfaction and Occupational Health and Safety}

Bringing a scientific definition to job satisfaction that represents an individual's happiness with his/her job is an effort that was started in the 1930s (Kornhauser \& Sharp, 1932). Although this is an extensively researched subject in organisational behavioural studies, there are no agreements as to its definition. From a chronological perspective, one of the first systematic definitions were made by Hoppock (1935). According to Hoppock, job satisfaction happens when various conditions come together. In other words, job satisfaction is the coming together of psychological, physiological, and environmental conditions enabling individuals to sincerely express they are pleased with their jobs (Hoppock, 1935). Afterwards, job satisfaction was conceptualised through emotions and thoughts 
individuals develop against their roles at work (Vroom, 1964). In the following periods, it was noted that job satisfaction expressed how individuals feel about their works and their relevant attitudes and behaviours (Davis \& Nestrom, 1985). Nonetheless, job satisfaction was described as the degree of overlap between expectations of workers from work and what they are faced with (Iverson \& Maguire, 2000). In other words, job satisfaction was described as a meeting of expectations of workers from work and their environments and their having satisfaction from and feeling happy about work and work results. Similarly, job satisfaction was also described as the emotional satisfaction received from completing duties with success and composing a product (Locke, 1969). In sum, job satisfaction can be described as the feeling of relieving happiness and being pleased with meeting expectations from work, work environment, and interaction with colleagues. Accordingly, if the expectations of employees are not met, job dissatisfaction emerges, which is a threat to organisations. Studies report that there are many benefits of job satisfaction; for instance, employees with high satisfaction are unlikely to leave organisations (Egan, Yang \& Bartlett, 2004); they tend to have higher job performance (Judge, Thoresen, Bono \& Patton, 2001); they have less absenteeism than those who are dissatisfied from their jobs (Hackett \& Guion, 1985). Considering these positive consequences, organisations should pay attention to the elements that play a role in increasing the job satisfaction of employees. Research emphasises that the decline of job satisfaction among employees is an adverse sign for organisations that working conditions might be deteriorating (Kılıç \& Selvi, 2009). In fact, extant literature illustrates that the working condition of employees is one of the factors that affect their job satisfaction. Some other factors include as follows; the nature of the job, wage, promotion opportunities, social relations in the workplace, management style, individual characteristics, among others (Başaran, 1999; Eroğlu, 2007; Soysal \& Tan, 2013).

After having examined relevant literature, working conditions of workplaces emerged as an important factor. Evidence from previous studies support this claim; for example, Frederic Taylor, who is the architect of business analysis studies with scientific methods in work environments, conducted studies emphasising the relationship between human physiology and the work environment. As a result, he came to the conclusion that the work environment is key in increasing the skills of employees and making jobs more efficient. Similarly, Maslow's hierarchy of needs (1943) suggests that an individual must be satisfied to pursue a higher level in the hierarchy of needs. To elaborate more, the theory demonstrates that the basic needs of individuals, such as safety, need to be met first. After satisfying basic needs, psychological needs can be satisfied. Based on the theory, it can be argued that health and safety measures are likely to affect employees' job satisfaction. Prior studies have found similar meaningful relationships between job satisfaction and health and safety perception. For instance, Ayim Gyekye (2005) conducted research that reports that employees with higher job satisfaction are more likely to have positive safety perceptions. In a study carried out by Kılıç \& Selvi (2009), it is revealed that health and safety risk factors such as physical, chemical and biological ones have impacts on job satisfaction of hotel employees. In a similar vein, Çınar and Gündoğdu (2019) reported that occupational health and safety has a positive effect on job satisfaction of employees. More recently, research conducted by Tatl1, Eğitmiş and Zümrüt (2021) found that there is a positive association between health and safety practices and job satisfaction of employees. Hence, considering previous studies and discussion above, the first hypothesis of the research is posited as following:

\section{H1: Occupational health and safety positively affects the job satisfaction}

\section{Role Ambiguity, Job Satisfaction and Occupational Health and Safety}

The concept of role is defined as a mechanism that comprises tasks and responsibilities of individuals (Jackson \& Schuler, 1985). Individuals undertake different roles based on their social status; for instance, a person can be a parent or son/daughter at home, while he/she can be a manager at the workplace. Based on that, each role poses distinct duties, and those who are affected by these roles attribute expectations to the roles (Van Sell, Brief \& Schuler, 1981). Hence, it can be argued that roles are not only linked to expectations but also shaped by them. 
Role ambiguity may emerge upon unclear definitions of tasks in roles. In other words, role ambiguity occurs if there is a lack of knowledge or not knowing the certain expectations to fulfil a role. Insufficient, vague and inconsistent knowledge about the responsibilities of roles often leads to role ambiguity (Pearce, 1981). Moreover, scholars define role ambiguity as to the dissonance between the provided information and the perception of the individual (Moorhead \& Griffin, 2010). Individuals might have several roles in their lives; while a role can be a manager in the workplace, another role could be a parent. If an individual experiences ambiguity about how to perform in his/her role at the workplace, it can be referred to as job role ambiguity which is focused in this research.

Employees might encounter role ambiguity in the workplace if there is ambiguity about what to do for their tasks or if employees do not know which expectations should be prioritised (Daft, 2010). Role ambiguity also stems from inadequate job descriptions, vague orders from managers, and complex words and behaviours from colleagues (Doğan, Demir \& Türkmen, 2016). Studies examining role ambiguity report that role ambiguity might lead to negative consequences. For instance, the research found a negative association between role ambiguity and job satisfaction (Abramis, 1994). Similarly, another study demonstrated that those employees who encounter role ambiguity are more likely to feel exhausted and burnout (Ghorpade, Lackritz \& Singh, 2011). Moreover, Elmas Atay and Gerçek conducted a study in 2017 in which they reached the conclusion that role ambiguity is positively associated with work alienation. Hence, as previous research highlights that role ambiguity might cause detrimental work behaviours, in the line of prior research, the second hypothesis of the study is posited as following:

\section{H2: Role ambiguity negatively affects the job satisfaction}

The extant literature highlights that OHS measures are crucial steps that need to be taken by organisations. These steps are generally related to working conditions. The availability of working in a safe and sound environment may lead to positive work behaviours. Recent research found that there is a positive relationship between work environment and employee performance (Nanzushi, 2015). Another study showed evidence that when organisations take necessary health and safety precautions, their employees tend to demonstrate higher productivity (Shikdar \& Sawaqed, 2003). From this point of view, poor and unsafe conditions are likely to cause counterproductive work behaviours. Based upon previous studies, OHS is expected to increase the job satisfaction of employees. In addition to this assumption, I argue that if employees perceive ambiguity in their roles, employees might feel dissatisfied with their jobs. Considering that the possibility of role ambiguity may play a moderating role between OHS and job satisfaction, the third hypothesis of the paper is posited as following:

\section{H3: Role ambiguity moderates the relationship between occupational health and safety and job satisfaction}

\section{Methodology}

To investigate the relationships between the variables, a quantitative methodology was adopted. Among the quantitative techniques, questionnaires were used to collect data as the study is causal in nature. Electronic questionnaires were generated using Google Forms. The link to the questionnaire was sent to participants for them to participate. There was a cover page in the questionnaires explaining the participant was voluntary, and the responses will be only used for academic purposes. The questionnaire was in Turkish.

Furniture manufacturing workers in Bursa were selected as a sample to test the hypotheses of the research model, which is illustrated in Figure 1. Purposive sampling was used for data collection because furniture manufacturing firms are rated as dangerous places to work. Hence, asking those workers who work at workplaces that require serious health and safety measures was likely to fit the purpose of the study. 


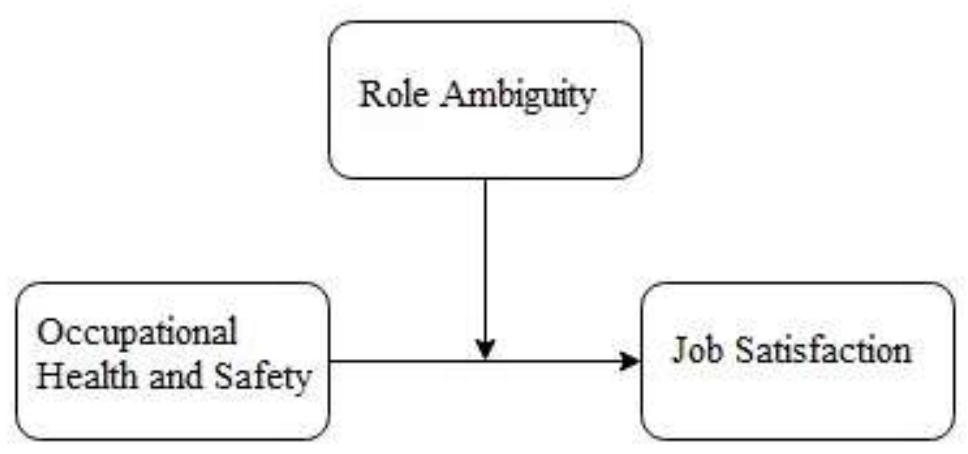

Figure 1: Proposed Research Model

Questionnaires were sent out to 437 possible participants. Only 213 questionnaires were completed. The response rate was $\% 48.11$ of returned questionnaires were not analysable due to missing information. Therefore, 202 participants provided valid questionnaires. The demographics of respondents were given in Table 1. Ethical approval was obtained from the Scientific Research and Publication Ethics Committee of Muş Alparslan University on 26/11/2020. The approval document number is E-10879717-050.01.04-13802 (Please see it in appendix I).

Table 1. Respondents Profile

\begin{tabular}{|c|c|c|c|}
\hline & & $\mathbf{N}$ & $\%$ \\
\hline \multirow{2}{*}{ Gender } & Male & 152 & $\% 75,2$ \\
\hline & Female & 50 & $\% 24,8$ \\
\hline \multirow{5}{*}{ Age } & $18-25$ & 18 & $\% 8,9$ \\
\hline & $26-35$ & 78 & $\% 38,6$ \\
\hline & $36-45$ & 73 & $\% 36,1$ \\
\hline & $46-55$ & 26 & $\% 12,9$ \\
\hline & Over 55 & 7 & $\% 3,5$ \\
\hline \multirow{5}{*}{ Education } & Elementary School & 86 & $\% 42,6$ \\
\hline & Secondary School & 36 & $\% 17,8$ \\
\hline & High School & 28 & $\% 13,9$ \\
\hline & Associate Degree & 28 & $\% 13,9$ \\
\hline & Bachelor degree & 24 & $\% 11,9$ \\
\hline \multirow{2}{*}{ Marital Status } & Single & 47 & $\% 23,3$ \\
\hline & Married & 155 & $\% 76,7$ \\
\hline \multirow{5}{*}{ Experience } & Less than a year & 26 & $\% 12,9$ \\
\hline & 1-3 year & 53 & $\% 26,2$ \\
\hline & 4-7 year & 42 & $\% 20,8$ \\
\hline & 8-11 year & 37 & $\% 18,3$ \\
\hline & Over 12 year & 44 & $\% 21,8$ \\
\hline \multirow{5}{*}{ Title } & Employee & 78 & $\% 38,6$ \\
\hline & Foreman & 50 & $\% 24,8$ \\
\hline & Supervisor & 34 & $\% 16,8$ \\
\hline & Manager & 17 & $\% 8,4$ \\
\hline & Other (Clean, Security Personnel) & 23 & $\% 11,4$ \\
\hline
\end{tabular}

\section{Measures}

The 30 items scale of occupational health and safety developed by Üngüren and Koç (2015) was adapted for the study. The scale of job satisfaction with 5 items was developed by Brayfield and Rothe (1951). The Turkish version of the scale was used, which is adapted to Turkish by Keser and Öngen 
Bilir (2019). The scale of the role ambiguity was adopted for the study, which was developed by Rizzo, House and Lirtzman (1970) and adapted to Turkish by Doğan, Demir and Türkmen (2016).

\section{Results}

Initially, the normality of the distribution in variables was studied. Thus, skewness and kurtosis values of scale items were examined. As a result of the test scale, items were determined to have values between -1.5 and 1.5. Thus, scales were assumed to have a normal distribution (Tabachnick, Fidell \& Ullman, 2007). Before testing hypotheses, validity and reliability analysis were conducted for scales used in the study. Thus, variables were initially tested for suitability for factor analysis. According to the results of KMO and Bartlett suitability tests, data were determined to be suitable for factor analysis $\left(\mathrm{KMO}=0,963 ; \chi^{2}=6482,338\right)$. The analysis of factor analyses is given in Table 2.

Table 2. The Validity and Reliability Analysis Results

\begin{tabular}{|c|c|c|c|c|}
\hline Variables & Items & Factor Loadings & Variance & Cronbach's $\alpha$ \\
\hline \multirow[t]{4}{*}{ Job Satisfaction } & JS1 & ,525 & 2,725 & ,887 \\
\hline & JS2 & ,860 & & \\
\hline & JS3 & ,497 & & \\
\hline & JS4 & ,504 & & \\
\hline \multirow[t]{6}{*}{ Role Ambiguity } & RA1 & ,691 & 3,743 & ,953 \\
\hline & RA2 & ,506 & & \\
\hline & RA3 & ,615 & & \\
\hline & RA4 & ,922 & & \\
\hline & RA5 & ,933 & & \\
\hline & RA6 & 649 & & \\
\hline \multirow{18}{*}{$\begin{array}{l}\text { Occupational Health } \\
\text { and Safety }\end{array}$} & OHS1 & ,742 & 66,900 & ,970 \\
\hline & OHS2 & 681 & & \\
\hline & OHS3 & ,726 & & \\
\hline & OHS4 & ,940 & & \\
\hline & OHS5 & ,820 & & \\
\hline & OHS6 & ,848 & & \\
\hline & OHS7 & ,895 & & \\
\hline & OHS9 & 690 & & \\
\hline & OHS10 & ,772 & & \\
\hline & OHS11 & ,597 & & \\
\hline & OHS13 & ,784 & & \\
\hline & OHS14 & ,777 & & \\
\hline & OHS15 & ,726 & & \\
\hline & OHS16 & 637 & & \\
\hline & OHS18 & ,792 & & \\
\hline & OHS19 & ,886 & & \\
\hline & OHS20 & ,823 & & \\
\hline & OHS21 & 667 & & \\
\hline
\end{tabular}

Results of factor analysis demonstrated that scale items were distributed to their places. In addition, it was determined that the occupational health and safety scale that is multidimensional in its original form was collected in a single dimension in our study. The remaining analysis was conducted in line with the new distribution. Also, item 5 of the job satisfaction scale and items 8, 12 and 17 of the occupational health and safety scale with factor loadings remaining below 0.50 were taken out of the analysis. Also, it was concluded that Cronbach's $\alpha$ values of scales were in acceptable limits; thus, there were no problems in terms of reliability. 


\section{Hypothesis Tests}

In order to test hypotheses formed in the scope of the study, multiple regression analysis was conducted using the SPSS v22 program (Aiken, West \& Reno, 1991) and conditions effects were analysed using Process Macro v3.5 add-in (Hayes, 2017). Results of the regression analysis were given in Table 3.

Table 3. Regression Analysis Results

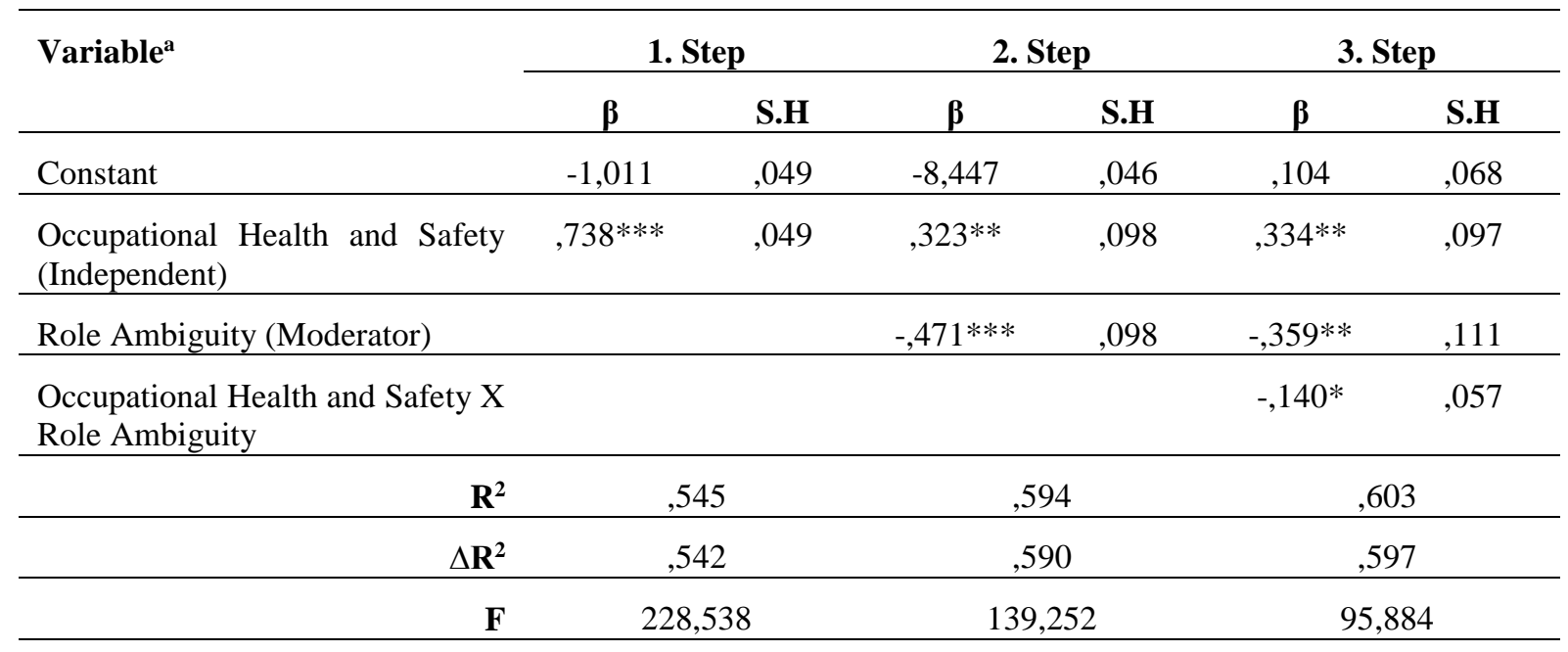

${ }^{\mathrm{a} D e p e n d e n t ~ V a r i a b l e ~}=$ Job Satisfaction; $* \mathrm{p}<0,05 ; * * \mathrm{p}<0,01 ; * * * \mathrm{p}<0,001$

As a result of the regression analysis, it was found that occupational health and safety had a positive and significant effect $(\beta=0.334 ; \mathrm{p}<0.01)$ on job satisfaction which is an independent variable, while role ambiguity had a negative and significant effect $(\beta=-0.359 ; \mathrm{p}<0.01)$. According to these findings of the study, "H1: OHS has a positive effect on job satisfaction" and "H2: Role ambiguity has a negative effect on job satisfaction" hypotheses were supported. Also, it was determined that the interaction term that was formed had a significant effect on job satisfaction. Thus, it was determined that role ambiguity moderated relationship between OHS and job satisfaction. As a result, "H3: Role ambiguity moderates the relationship between OHS and job satisfaction" hypothesis was accepted. The matrix prepared to determine the direction of moderating effect was presented in Figure 2. The percentage of the model explaining the dependent variable $\mathrm{R} 2=, 603$; The $\mathrm{F}$ value of model $=, 95,884$. 


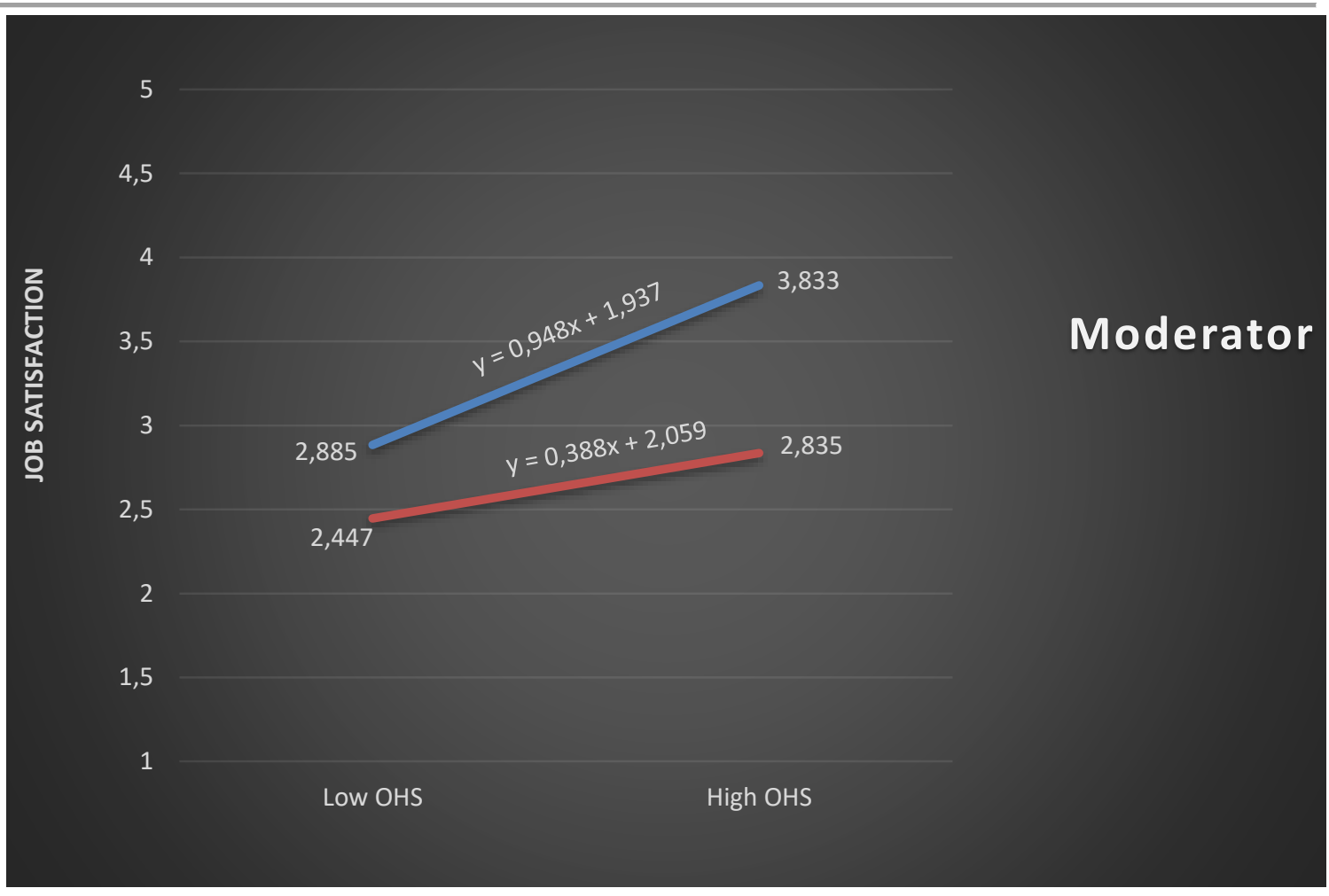

Figure 2. Moderation Effect Analysis

As can be seen from the drawn matrix, the fact that the lines are not parallel indicates that there is a moderation effect. In addition, according to the results of the contingent effect analysis made with the Process macro plugin, it was determined that the moderation is insignificant when the role ambiguity is low, and the moderation is significant when the perception of role ambiguity increases. Accordingly, it was concluded that role ambiguity reduces the positive relationship between OHS and job satisfaction.

\section{Discussion and Conclusion}

This paper aimed at examining the impact of occupational health and safety on job satisfaction and the moderation effect of role ambiguity on the relationship between occupational health and safety and job satisfaction. The research was conducted in furniture manufacturing firms in Bursa. The results showed that employees' perception of occupational health and safety affects their job satisfaction in a positive way. To elaborate, those employees who perceive that their workplace is taking necessary health and safety precautions are likely to be satisfied with their jobs. This can be explained by Maslow' theory of human motivation (1943). He states that the basics needs of humans, such as safety, should be satisfied first in order to move up for esteem needs. This study confirmed that OHS has a positive effect on job satisfaction; hence the first hypothesis of the research was supported. This result is in line with recent studies which found that there is a positive association between OHS practices and job satisfaction (Tatlı, Eğitmiş \& Zümrüt, 2021; Tatlıcan \& Çögenlin, 2020; Bilgin, Yalçınöz Baysal \& Hendekçi, 2019). Moreover, analyses demonstrated that having clarified the tasks and knowing what to do for a job leads to job satisfaction. In another saying, role ambiguity causes job dissatisfaction in the workplace. The extant literature suggests that written clear instructions and orders help employees about how to operate in the workplace. The results illustrated that the existence of obscure task definitions or insufficient information regarding tasks is likely to cause confusion which results in dissatisfied employees. This finding suggests that the second hypothesis is supported that role ambiguity negatively affects job satisfaction. The results of the confirmed hypothesis are overlapping with studies of Tarrant and Sabo (2010) and Koustelios, Theodorakis and Goulimaris (2004). 
As the third hypothesis, it was predicted that role ambiguity would have a moderating effect on the relationship between occupational health and safety and job satisfaction. The results suggested that when occupational health and safety steps are taken in the workplaces, it positively affects the job satisfaction of employees. Hence, on top of this argument, it was wondered if the role ambiguity variable would moderate the mentioned relationship. The analysis confirmed that role ambiguity has a moderation effect as ambiguous definitions of tasks are likely to change the effect of occupational health and safety on job satisfaction. This result extends current literature by emphasising the moderating effect of role ambiguity on the relationship between occupational health and safety and job satisfaction. This finding is also congruent with previous studies; for example, Gillet, Fouquereau, Lafrenière and Huyghebaert (2016) found that role ambiguity can serve as a moderator variable among other constructs. To the best knowledge of the author, there is no study that examined occupational health and safety as an independent variable, job satisfaction as a dependent variable and role ambiguity as a moderator variable together in a research model.

The findings of this paper offer practical implications to practitioners as well as policymakers. First and foremost, this study demonstrated that health and safety measures are not merely crucial for avoiding occupational hazards but also increasing job satisfaction levels of employees. Hence, managers should pay attention to taking all necessary measures for the health and safety of employees. By doing so, employees will be satisfied with their jobs which might lead employees to show higher performance and productivity. In the light of findings, managers should clearly state the job definitions, task instructions as well as expectations from employees to have a climate in which employees feel comfortable with their role. Following that, managers should enhance education and training programmes with an emphasis on occupational health and safety. Policymakers should not enact only laws regarding health and safety measures but also tighten the audits with higher fines. Lastly, employees should be aware that health and safety steps are not burdens; on the contrary, they are lifesaving measures that need to be taken seriously.

Despite the fact that this research has proposed an original model which contributes to the organisational behaviour literature, this paper also has some limitations. First, although this study used quantitative methods with self-reported questionnaires, future research may adopt face-to-face interviews to conceptualise the feelings and thoughts of employees regarding their perceptions of the studied concepts. Second, this study was conducted with 202 participants from Bursa, which make it hard to generalise the results to the whole population; however, future studies can increase the sample size by reaching more participants. Third, this research was carried out in furniture manufacturing firms in Bursa, as future research could include more cities and maybe different sectors such as the cement industry. Finally, this study investigated the impact of occupational health and safety on job satisfaction and the moderating role of role ambiguity on this relationship, and future studies may adopt different dependent variables such as organisational commitment, work engagement or organisational citizenship.

\section{References}

Abramis, D. J. (1994). Work role ambiguity, job satisfaction, and job performance: Meta-analyses and review. Psychological Reports, 75(3_suppl), 1411-1433.

Aiken, L. S., West, S. G., \& Reno, R. R. (1991). Multiple regression: Testing and interpreting interactions. Sage.

Ayim Gyekye, S. (2005). Workers' perceptions of workplace safety and job satisfaction. International Journal of Occupational Safety and Ergonomics, 11(3), 291-302.

Balkır, Z. G. (2012). İş sağlığ1 ve güvenliği hakkının korunması: işverenin iş sağlığ1 ve güvenliği organizasyonu. Sosyal Güvenlik Dergisi, 2(1), 56-91.

Başaran, İ. E. (1999). Örgütsel davranış. Ankara: Umut Yayıncılık. 
Bilgin, S., Yalçınöz Baysal, H. \& Hendekçi, A. (2019). Hastanede çalışan sağlık personelinin iş sağlı̆̆ı ve güvenliğine yönelik görüşleri ile iş doyumlarının belirlenmesi. Sağllk ve Toplum, 29(2), 43 49.

Brayfield, A. H \& Rothe, H. F. (1951). An index of job satisfaction. Journal of Applied Psychology, 35(5), 307-311.

Bunn III, W. B., Pikelny, D. B., Slavin, T. J., \& Paralkar, S. (2001). Health, safety, and productivity in a manufacturing environment. Journal of Occupational and Environmental Medicine, 43(1), 4755 .

Ceylan, H. (2021). Türkiye'de meydana gelen ölümlü iş kazaları. ÍSG Akademik, 3(1), 1-13.

Çınar, O. ve Gündoğdu, M. (2019). İş sağlığı-güvenliği, iş tatmini ve örgütsel bağlılık arasındaki ilişkinin incelenmesi: Erzurum ve İstanbul uygulaması. İs ve Hayat Dergisi, 5(9), 231-247.

Çiçek, Ö., \& Öçal, M. (2016). Dünyada ve Türkiye'de iş sağliği ve iş güvenliğinin tarihsel gelişimi. Hak İs Uluslararası Emek ve Toplum Dergisi, 5(11), 106-129.

Daft, R. L. (2010). New era of management, 9th Edition, South-Western, Cengage Learning, Canada.

Davis, K. \& Nestrom, J.W. (1985). Human behavior at work: Organisational behavior, 7 edition, McGraw Hill, New York.

Doğan, A., Demir, R., \& Türkmen, E. (2016). Rol belirsizliğinin, rol çatışmasının ve sosyal desteğin tükenmişliğe etkisi: devlet ve vakıf üniversitelerinde çalışan akademik personelin tükenmişlik düzeylerinin karşılaştırılması. Atatürk Üniversitesi İktisadi ve İdari Bilimler Dergisi, 30(1), 37 67.

Egan, T. M., Yang, B., \& Bartlett, K. R. (2004). The effects of organisational learning culture and job satisfaction on motivation to transfer learning and turnover intention. Human Resource Development Quarterly, 15(3), 279-301.

Elmas Atay, S., \& Gerçek, M. (2017). Algılanan rol belirsizliğinin işe yabancılaşma üzerindeki etkisinin ve demografik değişkenlere göre farklılıklarının incelenmesi. ODÜ Sosyal Bilimler Araştırmaları Dergisi, 7(2), 321-332.

Eroğlu, F. (2007). Davranış bilimleri. İstanbul: Beta Yayınc1lık.

Gençler, A. (2007). İşçi sağlığı ve iş güvenliğine ilişkin uygulamaların tarihi gelişimi, $\dot{I}_{S}$ Sağgl $\breve{g ̆}_{l}$ ve Güvenliği Dergisi, 7(35), 16-29.

Ghorpade, J., Lackritz, J., \& Singh, G. (2011). Personality as a moderator of the relationship between role conflict, role ambiguity, and burnout. Journal of Applied Social Psychology, 41(6), 12751298.

Gillet, N., Fouquereau, E., Lafrenière, M. A. K., \& Huyghebaert, T. (2016). Examining the roles of work autonomous and controlled motivations on satisfaction and anxiety as a function of role ambiguity. The Journal of Psychology, 150(5), 644-665.

Hackett, R. D., \& Guion, R. M. (1985). A reevaluation of the absenteeism-job satisfaction relationship. Organisational Behavior and Human Decision Processes, 35(3), 340-381.

Hayes, A. F. (2017). Introduction to mediation, moderation, and conditional process analysis: A regression-based approach. New York: Guilford publications.

Hoppock, R. (1935) Job satisfaction. New York: Arno Press.

Iverson, R. D., \& Maguire, C. (2000). The relationship between job and life satisfaction: Evidence from a remote mining community. Human Relations, 53(6), 807-839.

Jackson, S. E., \& Schuler, R. S. (1985). A meta-analysis and conceptual critique of research on role ambiguity and role conflict in work settings. Organisational Behavior and Human Decision Processes, 36(1), 16-78. 
Judge, T. A., Thoresen, C. J., Bono, J. E., \& Patton, G. K. (2001). The job satisfaction-job performance relationship: A qualitative and quantitative review. Psychological Bulletin, 127(3), 376-407.

Kılıç, G., \& Selvi, M. S. (2009). The effects of occupational health and safety risk factors on job satisfaction in hotel enterprises. Ege Akademik Bakış Dergisi, 9(3), 903-921.

Kılkış, İ. (2014). Işs sağllğg ve güvenliği Ed. Aysen Tokol ve Yusuf Alper, Sosyal politika, Bursa: Dora Basin Yayin.

Kornhauser, A. W., \& Sharp, A. A. (1932). Employee attitudes; suggestions from a study in a factory. Personnel Journal, 10, 393-404.

Koustelios, A., Theodorakis, N. \& Goulimaris, D. (2004). Role ambiguity, role conflict and job satisfaction among physical education teachers in Greece, International Journal of Educational Management, 18(2), 87-92.

Locke, E. A. (1969). What is job satisfaction?. Organisational behavior and human performance, 4(4), 309-336.

Maslow, A. H. (1943). A theory of human motivation. Psychological review, 50(4), 370-396.

Moorhead, G. \& Griffin, R. W. (2010). Organisational behavior: Managing people and organisations, 9th Edition, South-Western, Cengage Learning, China.

Nanzushi, C. (2015). The effect of workplace environment on employee performance in the mobile telecommunication firms in Nairobi city county (Doctoral dissertation, University of Nairobi).

Narter, S. (2015). İş kazası ve meslek hastalığında hukuki ve cezai sorumluluk, Ankara: Adalet Yayınevi.

Pearce, J. L. (1981). Bringing some clarity to role ambiguity research. Academy of Management Review, 6(4), 665-674.

Rizzo, J.R., House, R.J. \& Lirtzman, S.I. (1970). Role Conflict and Ambiguity in Complex Organisations. Administrative Science Quarterly, 15(2), 150-163.

Shikdar, A. A., \& Sawaqed, N. M. (2003). Worker productivity, and occupational health and safety issues in selected industries. Computers \& industrial engineering, 45(4), 563-572.

Soysal, A., \& Tan, M. (2013). İş tatminini etkileyen faktörlerle ilgili hizmet sektöründe yapilan bir araştirma: kilis ili kamu ve özel banka personeli örneği. Niğde Üniversitesi Iktisadi ve İdari Bilimler Fakültesi Dergisi, 6(2), 45-63.

Tabachnick, B. G., Fidell, L. S., \& Ullman, J. B. (2007). Using multivariate statistics. Boston, MA: Pearson.

Tambay, A. (2018). İş sağlığı ve güvenliği uygulamalarının örgütsel bağlılığa etkisinde psikolojik sözleşmenin aracılık rolü: Çimento sektöründe bir araştırma (Doctoral dissertation, Selçuk Üniversitesi Sosyal Bilimler Enstitüsui).

Tarrant, T., \& Sabo, C. E. (2010). Role conflict, role ambiguity, and job satisfaction in nurse executives. Nursing Administration Quarterly, 34(1), 72-82.

Tatlı, H. S., Eğitmiş, A. M., \& Zümrüt, M. Z. (2021). İş sağlı̆̆ı ve güvenliği uygulamalarının iş doyumuna etkisi: Çalışma yaşamı kalitesinin aracılık rolü. OPUS-Uluslararası Toplum Araştırmaları Dergisi, 18 (Yönetim ve organizasyon özel sayısı), 1256-1284.

Tatlıcan, M \& Çögenlin, M. Z. (2020). İş sağlığı ve güvenliği performans değerlendirme uygulamalarının iş tatmini üzerine etkisi: Endüstri işletmesi örneği. Uşak Üniversitesi Sosyal Bilimler Dergisi, 13(1), 181-194.

Van Sell, M., Brief, A. P., \& Schuler, R. S. (1981). Role conflict and role ambiguity: Integration of the literature and directions for future research. Human Relations, 34(1), 43-71.

Yiğit, A. (2011). İş güvenliği ve işçi să̆lı̆̆ , Bursa: Alfa Aktüel Yayınları. 